and Prof. A. R. Clapham outlined a project for preparing and publishing a set of distribution maps which should be comprehensive, accurate and readily available to botanical workers in Britain and elsewhere. A special committee was set up to inquire into the practicability of such a scheme, and the project, eventually made possible by a grant of $£ 10,000$ from the Nuffield Foundation, was launched at the Society's conference held recently in London.

The work is to be centred in Cambridge and is to take five years. Essentially, it consists of the accumulation in a convenient form of data of two main types-namely, individual species records (principally from the main public herbaria and the published literature), and field lists compiled by reliable workers - and the subsequent transference of these data to standard base-maps. Many possibilities of mapping were considered, and the final decision was to indicate by means of a conventional symbol the presence of each species within each $10-\mathrm{km}$. square of the Ordnance Survey National Grid. Such a map of the British Isles, reproduced at a size about 6 in. by 4 in., would reveal by a pattern of dots the broad features of distribution and its correlation with climate or geological formation ; moreover, the basis of any individual dot could be readily found by reference to the records.

There are some two thousand species of vascular plants in the British flora (an approximate figure including apomictic micro-species, but excluding most casuals), and there are more than $3,50010-\mathrm{km}$. grid squares. This may mean that a reasonably complete survey would accumulate $2,500,000$ $3,500,000$ individual records, a formidable undertaking for which a mechanically sortable punched. card system is clearly desirable, if not essential. Careful investigation of such systems revealed that not only did they possess great advantages in ease of handling and sorting, but also that it was possible to tabulate mechanically the individual maps from the set of cards referring to a particular species.

A Powers-Samas 40-column card installation has been chosen, by means of which data relevant to a particular record are coded, punched on to a small card and put in a permanent card index. This card index will be used not only for the immediate preparation of the maps, but also to provide the basis of a recording scheme for the Nature Conservancy, which, in addition to giving direct grants to the maps project, is financing this recording and mapping machinery. An incidental advantage in the use of punched cards is that quick and easy production of 'interim maps' during the working of the scheme is thereby made possible ; this can be a most important stimulus to further effort, as it can immediately reveal gaps in the existing records.

In addition to the great mass of information stored in literature and herbaria, it is hoped to utilize, particularly for the commoner species, the help of a great many amateur and professional botanists, who are being approached directly through universities, schools, national and local scientific and natural history societies. It is probably true to say that in helping in this scheme the field botanist can make a larger and more valuable contribution to accurate scientific knowledge than ever before.

Information on the scheme in general, and on the type of observations required from field botanists willing to co-operate, can be obtained from B.S.B.I. Distribution Maps Scheme, Botany School, Downing Street, University of Cambridge. S. M. WALTERS

\section{ROCKEFELLER FOUNDATION GRANTS}

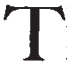

HE following grants to institutions and persons in Great Britain have been made by the Rockefeller Foundation, New York, for the first quarter of 1954 .

Medical Research Council of Great Britain : an appropriation of 125,000 dollars for fellowships in the medical sciences.

National Institute of Economic and Social Research, Great Britain : an appropriation of 60,000 dollars (to provide up to $£ 20,000$ ) for a study of the economic experience of the United Kingdom during 1945-53.

Royal Institute of International Affairs, London : an appropriation of 31,500 dollars (to provide up to $£ 10,500$ ) for the Institute in support of a study of race relations in Central Africa, under the direction of Mr. Philip Mason.

Royal Institute of International Affairs, London : 3,100 dollars to enable Miss Lois Simpson, press librarian, and Miss Helen G. Liddell, head of the Information Department, to visit the United States and Canada in connexion with their work at the Royal Institute.

University of Liverpool : 1,500 dollars toward travel and/or living expenses of foreign delegates invited to participate in a symposium on the comparative endocrinology of vertebrates to be held at Liverpool in July.

King's College, London : 8,000 dollars toward research in electrophysiology under the direction of Dr. Donald M. MacKay.

University College, London: 1,525 dollars to enable Prof. George C. Allen to renew his acquaintance with economic conditions and scholarly work in Japan and the United States in connexion with bringing up to date his work on the history of Japanese economic development.

University of London : an appropriation of 24,000 dollars for the purchase of an electron microscope to be used in King's College for research in biophysics under the direction of Prof. J. T. Randall.

Prof. F. W. Rogers Brambell, University College of North Wales, Bangor : 1,150 dollars toward travel and living expenses while extending his stay in the United States after taking part in the Cold Spring Harbor symposium on fotal physiology to be held in June.

Dr. John R. Ellis, sub-dean of the London Hospital Medical College : 2,150 dollars to permit him to visit medical schools in the United States to observe developments in medical education.

Prof. H. J. Eysenck, director of the Psychological Department, Institute of Psychiatry, University of London : 2,700 dollars for travel and expenses to visit centres of research in psychology in the United States and Canada.

Dr. F. P. Glees, lecturer and university demonstrator, Laboratory of Physiology, University of Oxford : 800 dollars to permit him to visit laboratories of neurophysiological research in the United States.

Dr. Hilde T. Himmelweit, London School of Economics and Political Science: 1,150 dollars to enable her to visit major research and training centres of social and clinical psychology in the United States.

Prof. Irene Manton, Department of Botany, University of Leeds : 700 dollars toward travel and 
living expenses in connexion with her proposed visit to the United States to study the uses of electron microscopy and to learn special methods of making ultra-thin sections of plant tissues.

Prof. K. R. Popper, London School of Economics and Political Science : $£ 960$ (about 2,800 dollars) to extend by six months a period of uninterrupted work on problems of social philosophy and the methodology of the social sciences.

Sir Dennis Robertson, professor of political economy in the University of Cambridge: 2,260 dollars to enable him to visit American universities and research centres.

Miss Margaret B. Swann, lecturer in the Department of Psychological Medicine, University of Glasgow : 2,400 dollars for travel and expenses to visit centres of psychiatric social work in the United States and Canada.

Prof. A. S. T. Thomson, professor of civil and mechanical engineering, Royal Technical College, Glasgow : 1,650 dollars for a visit to sanitary engineering centres in the United States.

Dr. J. Walker, senior lecturer in obstetries, University of Aberdeen : 400 dollars toward travel and living expenses for visits to laboratories of obstetric medicine research in the United States.

\section{USE OF SYNTHETIC DETERGENTS IN GREAT BRITAIN}

$\mathrm{T}$ HE increasing use of synthetic detergents has caused many people to ask themselves whether we shall not, sooner or later, have to pay for the benefits we get from them. Housewives, who use them for washing-up and other domestic purposes, have ascribed dermatitis and cracked skins to their use; some have doubted whether they do not cause corrosion of domestic utensils and plumbing; industrial users have had similar doubts; and the discharge of industrial and domestic detergents through the sewers has caused serious problems at some sewage works.

The interim report of the Committee on Synthetic Detergents* is therefore of interest to a public that is far wider than those exclusively concerned with the scientific, technical or commercial aspects of detergents. This Committee, appointed in May 1953, is still busily at work ; its general interim conclusion, however, is that there is, as yet, no evidence that users of synthetic detergents need be alarmed about the possible ill-effects of these substances, but that detergents may cause, at some sewage works, a definite nuisance and that they may possibly affect the efficiency of sewage treatment and also the condition of rivers and the purity of water supplies.

Dealing with the possibility that washing products based on synthetic detergents may cause dermatitis of the skin, the Committee says that these washing products may, indeed, thus affect the skins of some people, but that washing-products based on soaps and alkalis may also do this. Medical opinion is apparently variable on this question, but, in spite of the widespread use of synthetic detergents throughout Britain, dermatitis is not more frequent either in households or industries than it was when washingproducts based on soaps and alkalis were used. * Ministry of Housing and Local Government. Interim Report of
the Committee on Synthetic Detergents. Pp. 8. (London: H.M.S.O., 1954.) $4 d$. net.
Many housewives use hand-creams after using synthetic detergents, and they should be taught how much of them to use and not to use them in excessive quantities. There is no evidence that traces of these substances left on crockery or other utensils may get into food or drink and have ill effects. Detergents may remove films of grease or soap from household utensils and plumbing systems and may thus expose them to corrosion, but kitchen utensils and pipes have been exposed for years to corrosive substances containing soda and chlorine and no corrosion problem has arisen. The Committee considers that problems of this kind may be left to the makers of kitchen utensils and furniture.

The most serious problem is the effect of detergents on sewage disposal. The detergents continue to produce foam after they have been discharged into the sewers, and the foam may rise, at some sewage works, to a height of several feet, especially at works where the activated sludge system is used. At some sewage works the foam endangers the operatives and, when it drifts off from the works, it becomes offensive to the neighbourhood; because it may contain particles of unpurified sewage, its suppression is a problem of public health. Although this kind of problem may become more acute, it need not, at present, cause alarm. Further research on methods of suppression of the foom is needed, and it is now going on.

Equally important, or perhaps more so, is the possibility that detergents may add to the difficulty being experienced at some sewage works of keeping the effluents up to the required standard. The Committee is giving special attention to this problem. It is also specially concerned with the discharge of effluents containing detergents into rivers, where they may affect water supplies drawn from the rivers, or the life of animals living in the rivers.

The Committee's experimental work is made more difficult by the fact that large-scale experimental work on sewage and on water supplies is restricted by law and by the need to safeguard the purification of water and sewage. An additional difficulty is the differing chemical composition of the various detergents, none of which is a single chemical substance, so that accurate methods of determining small concentrations of them have still to be devised. The Committee does not, for these reasons, expect to be able to finish its work quickly and gives a warning that all generalizations made about the effects of detergents must be treated with great caution.

\section{PLAY IN DOMESTIC CATTLE IN BRITAIN : AN ANALYSIS OF ITS NATURE}

THERE is no universally accepted theory of the genesis and goal of play. A. Brownlee, of the Agricultural Research Council Field Station, has recently investigated the manifestations and conditions of occurrence of play in cattle. From his observations he has also carried out both analysis and synthesis in the light of more recent studies of instinctive behaviour and of physiological processes in muscle and the other tissues concerned in play (Brit. Vet. J., 110, No. 2; 1954).

For the most part the observations were carried out intermittently over a period of years on cattle 